\title{
Combined Pulmonary Fibrosis and Emphysema (CPFE)
}

\author{
Keisaku Fujimoto ${ }^{1}$ and Yoshiaki Kitaguchi ${ }^{2}$ \\ ${ }^{1}$ Department of Clinical Laboratory Sciences, \\ Shinshu University School of Health Sciences. \\ ${ }^{21} 1^{\text {st }}$ Department of Internal Medicine, Shinshu University School of Medicine. \\ Nagano, \\ Japan
}

\section{Introduction}

Combined pulmonary fibrosis and emphysema (CPFE) is one of smoking-related lung diseases.

Emphysema is characterized by the permanent abnormal enlargement of airspaces distal to the terminal bronchioles, accompanied by destruction of their walls. The characteristics of emphysema do not, by definition, include thickening of the alveolar septa and fibrosis. However, coincidental idiopathic pulmonary fibrosis (IPF) and emphysema was firstly reported in 1990 by Wiggins et al (Wiggins J, et al., 1990) in London. Smoking-related interstitial lung diseases (SRILD) include desquamative interstitial pneumonia (DIP), respiratory bronchiolitis-related interstitial lung disease (RB-ILD), pulmonary Langerhans' cell histiocytosis (LCH) and idiopathic pulmonary fibrosis (IPF) (Ryu JH, et al., 2001). Tobacco smoking is also major course of emphysema and chronic obstructive pulmonary disease (COPD). Smoking is a common risk factor for both emphysema and pulmonary fibrosis. Recently, the occurrence of both emphysema and pulmonary fibrosis in the same patient has received increased attention as the syndrome of combined pulmonary fibrosis and emphysema (CPFE) (Cottin V, et al., 2005). It has been demonstrated that CPFE syndrome is not rare because on a series of 110 patients with IPF, $28 \%$ of them with at least $10 \%$ of the lung affected with emphysema, and thus are considered to have CPFE (Mejia M, et al., 2009).

\section{Clinical characteristics of CPFE}

In Japan Hiwatari et al (Hiwatari N, et al., 1993) reported nine patients with pulmonary emphysema and IPF among 152 pulmonary emphysema patients in 1993. Those patients were all men and heavy smokers. Odani et al (Odani K, et al., 2004) reported 31 patients combined with pulmonary emphysema and IPF among 14900 patients who underwent chest CT from January 1996 to March 2001 at Kochi Medical School Hospital in Japan. The CT of all patients showed the coexistence of emphysema with upper lung field predominance and diffuse parenchymal lung disease with significant pulmonary fibrosis predominantly in the lower lung fields (Figure 1). Centriacinar emphysema was present in 24 of the $31(77 \%)$ 
patients and paraseptal emphysema in 11 of 31 patients (35\%). Honeycombing, which is one of the most common findings of usual interstitial pneumonia, was present in 24 of the 31 patients (77\%). In 2005 Cottin et al (Cottin V, et al., 2005) conducted a retrospective study of 61 patients with CPFE and characterized this association as a distinct entity. They reported that sixty patients were male, dyspnea on exertion was present in all patients, basal crackles were found in $87 \%$ and finger clubbing in $43 \%$. Pulmonary function tests showed preserved lung volumes and strongly impaired lung diffusing capacity for carbon monoxide (DLCO). They showed that pulmonary hypertension was frequent in patients with CPFE with $47 \%$ of patients with estimated systolic right ventricular pressure $\geqq 45 \mathrm{mmHg}$ at echocardiography and the 5-yr probability of survival was $25 \%$ in patients with pulmonary hypertension compared with $75 \%$ in those without pulmonary hypertension at diagnosis (Figure 2). They also confirmed these findings by right heart catheterization on a retrospective multicenter study and concluded that the patients with CPFE and pulmonary hypertension have a dismal prognosis despite moderately altered lung volume and flows (Cottin V, et al., 2010). The risk of developing pulmonary hypertension is much higher in CPFE than in IPF without emphysema (Mejia M, et al., 2009). Pulmonary hypertension was a critical determinant of the prognosis.

a)
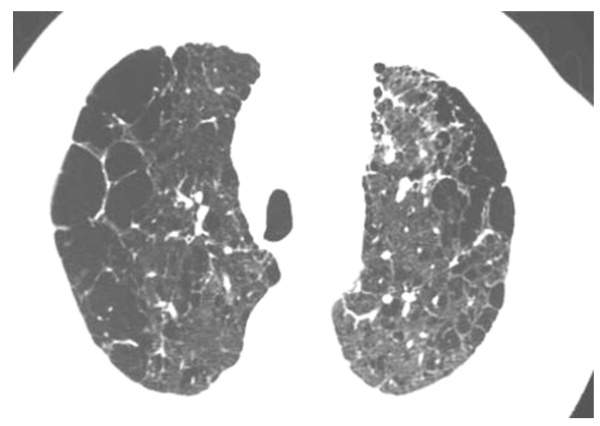

b)

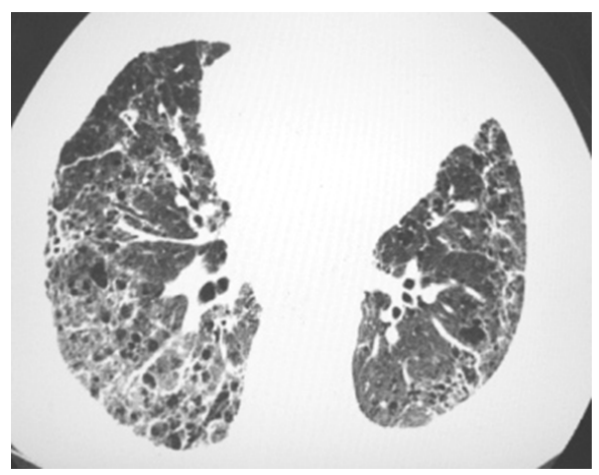

Fig. 1. Imaging in a 66-year-old male with combined pulmonary fibrosis and emphysema (CPFE). Chest high-resolution computed tomography of the bilateral upper lung fields (a) shows centriaciner + paraseptal emphysema with thick walled bulla and of the bilateral lower lung fields (b) shows reticular opacities and traction bronchiectasis. 


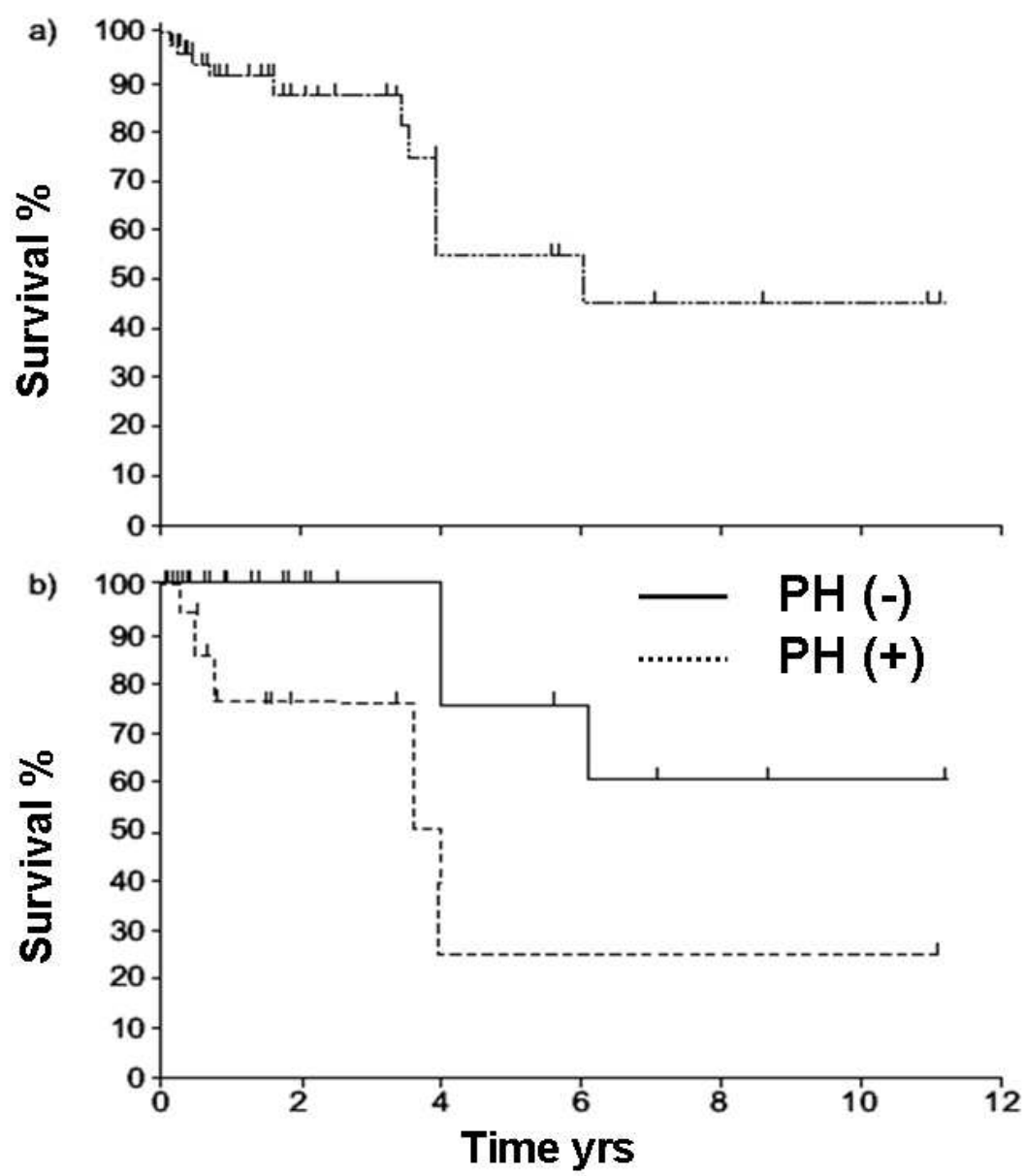

Fig. 2. Total survival of patients with combined pulmonary fibrosis and emphysema (CPFE) (a); 5-yr survival was 55\%. Survival for subjects with CPFE stratified on the basis of pulmonary hypertension (PH) (b); 5-yr survival was significantly less in patients with pulmonary hypertension (25\%) compared with those without pulmonary hypertension (75\%) at diagnosis.

We retrospectively examined the clinical characteristics of 47 patients with CPFE based on the findings of chest HRCT consecutively recruited from outpatients attending Shinshu University Hospital between October 2004 and June 2007 (Kitaguchi Y, et al., 2010). The clinical characteristics of CPFE patients were compared with those of emphysema-dominant COPD patients without parenchymal lung disease (COPD without fibrosis). Forty-six of the 47 CPFE patients were male. Paraseptal emphysema was particularly common in the CPFE group, although centriacinar was dominant in the COPD without fibrosis (Table 1). All CPFE patients showed the coexistence of emphysema with upper lung fields predominance and diffuse parenchymal lung disease with significant pulmonary fibrosis with lower lung 
fields predominance. Honeycombing, ground-glass opacities and reticular opacities were present in $75.6 \%, 62.2 \%$ and $84.4 \%$ of CPFE patients, respectively. Thick-walled bullae were characteristic in CPFE and observed in more than one half of the CPFE patients.

Twenty-seven of the 47 CPFE patients $\left(57.4 \%\right.$ ) showed a $\mathrm{FEV}_{1} / \mathrm{FVC}$ ratio within the normal range and the other patients showed milder airflow limitation, although the presence of severe emphysema (Table 2, 3). All CPFE patients showed lower lung volume and DLCO than the patients with COPD without fibrosis as previously reported. Desaturation during 6-min walking test in CPFE patients tended to be more severe than in COPD without fibrosis patients, if the level of $\mathrm{FEV}_{1}$ or 6-minute walking distance was equal (Figure 3). These findings suggest that CPFE patients show severe dyspnea and severe hypoxemia on effort in spite of subnormal spirometry findings.

\begin{tabular}{|l|l|l|}
\hline & CPFE & COPD \\
\hline LAA score & $13.2 \pm 0.9^{* *}$ & $18.9 \pm 0.7$ \\
\hline Upper lobe & $5.6 \pm 0.3^{* *}$ & $6.7 \pm 0.2$ \\
\hline Middle lobe & $4.3 \pm 0.3^{* *}$ & $6.2 \pm 0.2$ \\
\hline Lower lobe & $3.3 \pm 0.4^{* *}$ & $5.9 \pm 0.3$ \\
\hline Emphysema type & & \\
\hline centriacinar, $\%$ & $11(24.4 \%)^{* *}$ & $49(59.8 \%)$ \\
\hline panacinar+centriacinar, $\%$ & $7(15.6 \%)^{*}$ & $26(31.7 \%)$ \\
\hline paraseptal, $\%$ & $15(33.3 \%)^{* *}$ & $7(8.5 \%)$ \\
\hline paraseptal+centriacinar, $\%$ & $12(26.7 \%)^{* *}$ & $0(0.0 \%)$ \\
\hline IP distribution & & \\
\hline Upper lobe & $8(17.0 \%)$ & \\
\hline Middle lobe & $18(38.3 \%)$ & \\
\hline Lower lobe & $47(100.0 \%)$ & \\
\hline IP pattern & & \\
\hline Thick-walled bulla, $\mathrm{n}(\%)$ & $26(57.8 \%)$ & \\
\hline honeycombing, $\mathrm{n}(\%)$ & $34(75.6 \%)$ & \\
\hline reticular opacity, $\mathrm{n}(\%)$ & $38(84.4 \%)$ & \\
\hline ground glass opacity, $\mathrm{n}(\%)$ & $28(62.2 \%)$ & \\
\hline consolidation, $\mathrm{n}(\%)$ & $6(13.3 \%)$ & \\
\hline traction bronchiectasis, $\mathrm{n}(\%)$ & $18(40.0 \%)$ & \\
\hline peribronchovascular thickening, $\mathrm{n}(\%)$ & $4(8.9 \%)$ & \\
\hline architectural distortion, $\mathrm{n}(\%)$ & $7(15.6 \%)$ & \\
\hline
\end{tabular}

Values are the mean \pm SEM $\cdot{ }^{*} \mathrm{p}<0.05$ and ${ }^{* *} \mathrm{p}<0.01$ vs. COPD.

Table 1. Chest HRCT findings in patients with combined pulmonary fibrosis and emphysema (CPFE, $n=47$ ) and emphysema dominant COPD without fibrosis (COPD, $n=82$ ). 


\begin{tabular}{|l|l|l|}
\hline & CPFE & COPD \\
\hline number & 47 & 82 \\
\hline Sex, female/male & $1 / 46$ & $8 / 74$ \\
\hline Body mass index, $\mathrm{kg} / \mathrm{m}^{2}$ & $22.9 \pm 0.4^{* *}$ & $20.5 \pm 0.3$ \\
\hline Smoking history, packs $\cdot$ year & $58.7 \pm 4.4$ & $59.4 \pm 3.0$ \\
\hline Non-COPD & $27(57.4 \%)$ & $0(0.0 \%)$ \\
\hline COPD & $20(42.6 \%)$ & $82(100.0 \%)$ \\
\hline Stage I & $8(17.0 \%)$ & $8(9.8 \%)$ \\
\hline Stage II & $8(17.0 \%)^{* *}$ & $34(41.5 \%)$ \\
\hline Stage III & $4(8.5 \%)^{* *}$ & $30(36.6 \%)$ \\
\hline StageIV & $0(0.0 \%)^{*}$ & $10(12.2 \%)$ \\
\hline Complication of lung cancer $\cdot \mathrm{n}(\%)$ & $22(46.8 \%)^{* *}$ & $6(7.3 \%)$ \\
\hline squamous cell carcinoma & $12(54.5 \%)^{* *}$ & $3(50.0 \%)$ \\
\hline small cell carcinoma & $2(9.1 \%)$ & $0(0.0 \%)$ \\
\hline adenocarcinoma & $7(31.8 \%)$ & $3(50.0 \%)$ \\
\hline LCNEC & $1(4.5 \%)$ & $0(0.0 \%)$ \\
\hline
\end{tabular}

$\mathrm{n}(\%)$, Values are the mean \pm SEM $\cdot{ }^{*} \mathrm{p}<0.05$ and ${ }^{* *} \mathrm{p}<0.01$ vs. COPD.

Table 2. Clinical characteristics in patients with combined pulmonary fibrosis and emphysema (CPFE) and emphysema dominant COPD without fibrosis (COPD).

\begin{tabular}{|l|l|l|}
\hline & CPFE & COPD \\
\hline$\%$ VC, $\%$ & $94.7 \pm 3.5$ & $96.6 \pm 2.4$ \\
\hline FEV1, \% of pred. & $79.0 \pm 3.1^{* *}$ & $54.7 \pm 2.7$ \\
\hline FEV1/FVC, \% & $71.8 \pm 2.0^{* *}$ & $48.0 \pm 1.2$ \\
\hline FRC, \% of pred. & $89.9 \pm 5.8^{* *}$ & $112.5 \pm 2.7$ \\
\hline RV, \% of pred. & $114.7 \pm 10.3^{* *}$ & $181.7 \pm 5.5$ \\
\hline $\mathrm{RV} / \mathrm{TLC}, \%$ & $37.3 \pm 1.9^{* *}$ & $50.5 \pm 1.1$ \\
\hline$\% \mathrm{DLco}, \%$ & $39.6 \pm 2.5^{* *}$ & $57.7 \pm 2.2$ \\
\hline $\mathrm{PaO}$, torr & $68.6 \pm 2.3$ & $70.0 \pm 1.3$ \\
\hline $\mathrm{PaCO} 2$, torr & $39.3 \pm 0.9$ & $40.5 \pm 0.6$ \\
\hline $\mathrm{a} 1-\mathrm{AT}, \mathrm{mg} / \mathrm{dl}$ & $153 \pm 15$ & $190 \pm 38$ \\
\hline $\mathrm{CRP}, \mathrm{mg} / \mathrm{dl}$ & $1.1 \pm 0.3$ & $0.5 \pm 0.1$ \\
\hline $\mathrm{KL}-6, \mathrm{U} / \mathrm{ml}$ & $1058 \pm 166$ & - \\
\hline
\end{tabular}

Values are the mean \pm SEM $\cdot{ }^{* *} \mathrm{p}<0.01$ vs. COPD.

Table 3. Pulmonary function tests and laboratory data in patients with combined pulmonary fibrosis and emphysema (CPFE, $n=47$ ) and emphysema dominant COPD without fibrosis (COPD, n=82). 

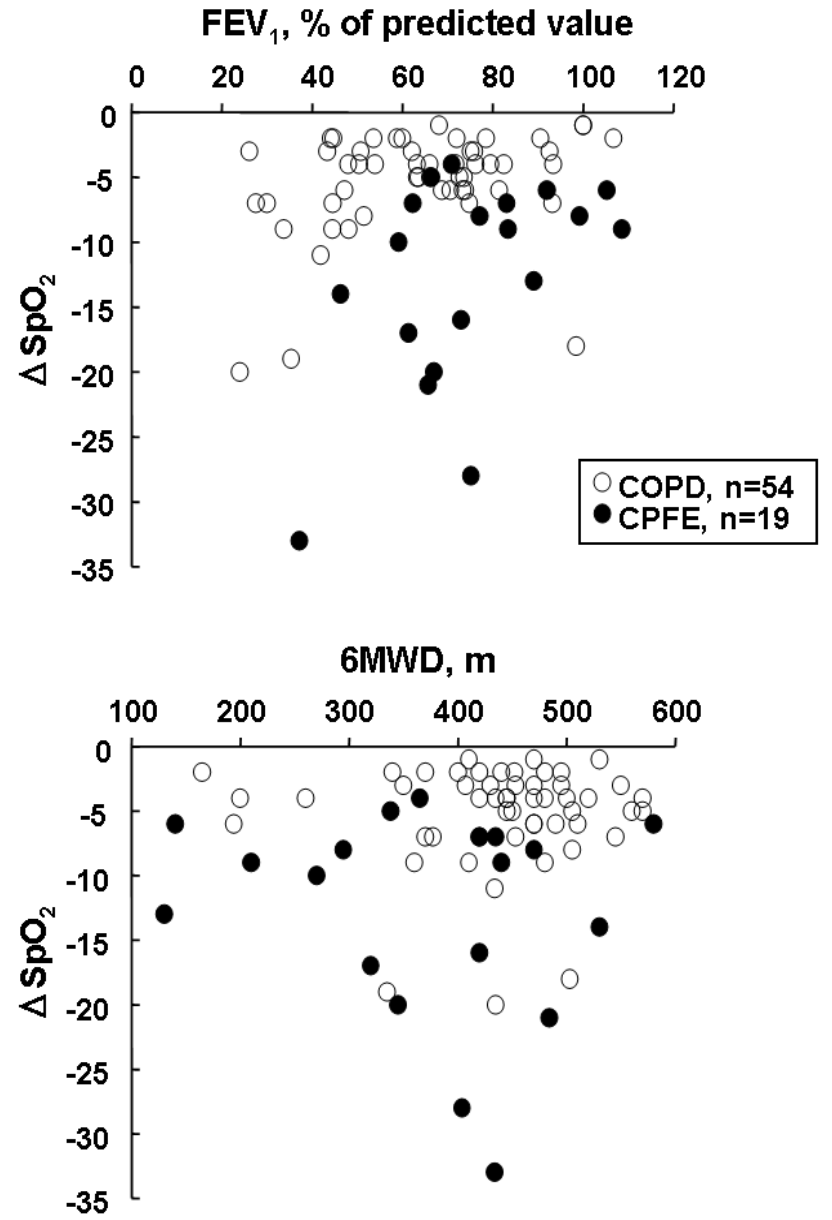

Fig. 3. Relationship between $\triangle \mathrm{SpO}_{2}$ during a 6-minute walking test and FEV1 or 6 minutewalking distance (6MWD) in patients with combined pulmonary fibrosis and emphysema (CPFE) and emphysema dominant COPD without fibrosis (COPD).

\section{Higher incidence of lung cancer}

In the series of our retrospective study, twenty-two of the 47 CPFE patients (46.8\%) had lung cancer whereas only $7.3 \%$ of the patients with COPD without fibrosis had (Table 2) (Kitaguchi Y, et al., 2010). There were no significant differences in histological type of cancer between CPFE and COPD without fibrosis group. Odani et al (Odani K, et al., 2004) also reported higher incidence of lung cancer and 42\% (13 patients) of CPFE were complicated lung cancer as well as our report and squamous cell carcinoma was the most common histological type. On the other hand, Nakayama et al reported that 18 of 127 patients with COPD $(14 \%)$ were complicated with lung cancer in Japan (Nakayama M, et al., 2003). 
According to a clinical study of IPF based on autopsy studies in elderly patients performed in Japan, lung cancer developed in approximately 23\% of the IPF patients (Araki T, et al., 2003). Therefore, the complicated ratio of lung cancer might be higher in CPFE patients than in COPD and IPF patients. However, the evidence is poor because of retrospective study and a single institution study may have some selection bias. Further investigations are needed to clarify whether CPFE is an independent risk factor for lung cancer, its role in susceptibility to lung cancer.

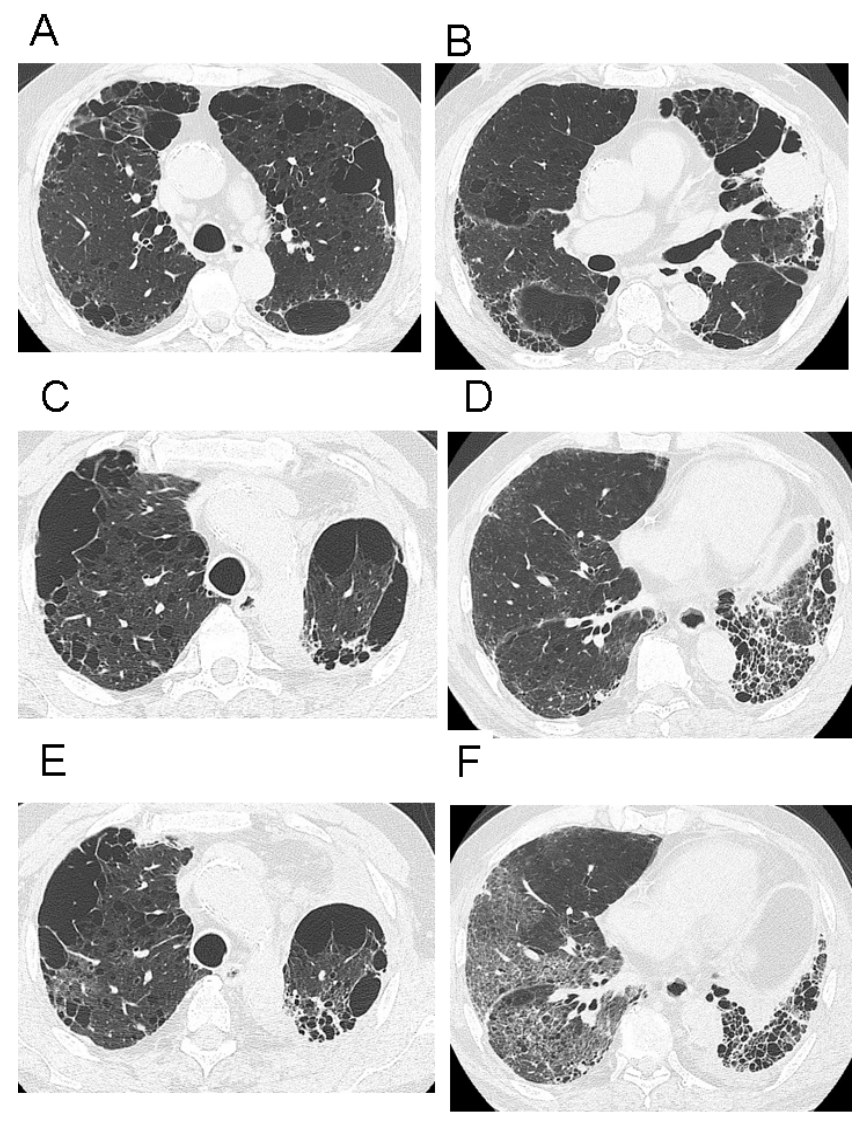

Fig. 4. Imaging in a 78-year-old male with CPFE complicated with lung cancer (squamous cell carcinoma) in the left lung S4. Chest HRCT images before left upper lobectomy (A, B) and after upper lobectomy (C, D). Two months later, the patients developed exacerbation of interstitial pneumonia, new diffuse bilateral ground-glass opacities superimposed on a background of reticular opacities and honeycombing with basal and peripheral predominance $(\mathrm{E}, \mathrm{F})$.

When the patients with CPFE are complicated with lung cancer, it may have a profound influence on their prognosis because of poor operability and difficulties in chemotherapy. Usui et al (Usui K, et al., 2011) retrospectively reviewed the data for 1143 patients with lung 
cancer. CPFE, emphysema and fibrosis were identified in $8.9 \%, 35.3 \%$ and $1.3 \%$ patients with lung cancer, retrospectively. The median overall survival of CPFE patients was significantly less than that of normal patients or that of patients with emphysema alone. Of interest, $76 \%$ of lung cancers in patients with CPFE were diagnosed at an advanced stage. Also, fatal severe acute lung injury occurred more frequently (19.8\%) in CPFE, irrespective of the treatment modality. Especially, postoperative lung injury occurred in nine of 33 patients with CPFE. Therefore, the presence of CPFE may be higher risk for postoperative lung injury as well as the presence of interstitial lung disease (Chiyo M, et al., 2003). Figure 4 shows imaging in a 78-year-old male with CPFE complicated with lung cancer (squamous cell carcinoma) in the segment 4 of left lung admitted to our hospital. He was underwent left upper lobectomy for lung cancer. However, two months later, he developed severe exacerbation of interstitial pneumonia, and dies due to respiratory failure.

\section{Pathogenesis}

Little is known about the pathogenesis of CPFE. Concerning with parenchymal lung disease in CPFE, usual interstitial pneumonia (UIP) has been the most common histopathological finding, and there are no differences in histological findings from IPF. IPF and pulmonary emphysema have distinct clinical and pathological characteristics, and have been considered to be separate disorders. In spite of such differences, animal experiments have suggested that the same lung injury might result in either fibrosis or emphysema. Connective tissue synthesis during the healing phase may be the critical determinant (Niewoehner DE, et al., 1982). Hoyle et al. (Hoyle GW, et al., 1999) reported that the overexpression of plateletderived growth factor-B induced both emphysema and fibrotic lung disease in the developing and adult lung of transgenic mice. It has been also shown that the overexpression of TNF-alpha driven by the surfactant protein C promoter (Lundblad LK, et al., 2005), IL-13 (Fulkerson PC, et al., 2006), and transforming growth factor-beta 1 (Lee CG, et al., 2006) in transgenic mice induces pathological changes consistent with both emphysema and pulmonary fibrosis. These pathological changes might represent an experimental animal model of CPFE. The tissue effects of these factors might depend on the balance of apoptosis, proteolysis and fibrosis and might regulate the degree of emphysema and/or fibrosis in the injured lung. It has been recently reported a 32-year-old women, never smokers, with CPFE and her daughter at 3 months of age showed having fibrosing interstitial pneumonia, and both the mother and daughter had a mutation of the surfactant protein-C (SFTPC) gene (Cottin V, et al., 2011). It is suggested that an individual's genetic background may predispose some smokers to the development of CPFE. Further studies are needed to elucidate these phenomena.

\section{Conclusion}

CPFE patients had some different clinical characteristics in comparison with emphysema and interstitial lung disease and should be included as a smoking-related lung disease. The patients with CPFE show severe dyspnea, unexpected subnormal spirometry findings, severely impaired DLCO, hypoxemia at exercise, characteristic imaging feature, and a high probability of severe pulmonary hypertension and lung cancer. A strict follow-up is therefore required because of higher rate of complicated pulmonary hypertension and lung 
cancer and acute exacerbation may occur after lung surgery in CPFE. HRCT plays an important role in diagnose $\mathrm{CPFE}$ and evaluating the occurrence of lung cancer and an acute exacerbation of CPFE. CPFE syndrome is an important entity and is a matter of growing interest by respiratory clinicians.

\section{Reference}

Araki T, Katsura H, Sawabe M, Kida K. A clinical study of idiopathic pulmonary fibrosis based on autopsy studies in elderly patients. Intern. Med. 2003; 42: 483-9.

Chiyo M, Sekine Y, Iwata $\mathrm{T}$ et al. Impact of interstitial lung disease on surgical morbidity and mortality for lung cancer: analyses of short-term and long-term outcome. J Thorac Cardiovasc Surg 2003; 126: 1141-6.

Cottin V, Le Pavec J, Prevot G, et al. Pulmonary hypertention in patients with combined pulmonary fibrosis and emphysema syndrome. Eur Respir J 2010; 35: 105-111.

Cottin V, Nunes H, Brillet PY, et al. Combined pulmonary fibrosis and emphysema: a distinct underrecognised entity. Eur Respir J 2005 26: 586-93.

Cottin V, Reix P, Khouatra C, et al. Combined pulmonary fibrosis and emphysema syndrome associated with familial SFTPC mutation. Thorax , 2011.

Fulkerson PC, Fischetti CA, Hassman LM et al. Persistent effects induced by IL-13 in the lung. Am. J.Respir.CellMol.Biol. 2006; 35: 337-46.

Hiwatari N, Shimura S, Takishima T. Pulmonary emphysema followed by pulmonary fibrosis of undetermined cause. Respiration 1993; 60: 354-8.

Hoyle GW, Li J, Finkelstein JB et al. Emphysematous lesions, inflammation, and fibrosis in the lungs of transgenic mice overexpressing platelet-derived growth factor. Am. J. Pathol. 1999; 154: 1763-75.

Kitaguchi Y, Fujimoto K, Hanaoka M, et al. Clinical characteristics of combined pulmonary fibrosis and emphysema. Respirology 2010 15: 265-71.

Lee CG, Cho S, Homer RJ et al. Genetic control of transforming growth factor-beta1induced emphysema and fibrosis in the murine lung. Proc. Am. Thorac. Soc. 2006; 3: 476-7.

Lundblad LK, Thompson-Figueroa J, Leclair $\mathrm{T}$ et al. Tumor necrosis factor-alpha overexpression in lung disease: a single cause behind a complex phenotype. Am. J. Respir. Crit. CareMed. 2005; 171: 1363-70.

Mejia M, Carrillo G, Rojas-Serrano J, et al. Idiopathic pulmonary fibrosis and emohysema: decreased survival associated with severe pulmonary arterial hypertension. Chest 2009; 136: 10-15.

Nakayama M, Satoh H, Sekizawa K. Risk of cancers in COPD patients. Chest. 2003; 123: 1775-6.

Niewoehner DE, Hoidal JR. Lung fibrosis and emphysema: divergent responses to a common injury? Science 1982; 217: 359-60.

Odani K, Murata Y, Yoshida S. Computed Tomographic Evaluation in the Cases of Coexistence of Pulmonary Emphysema with Idiopathic Pulmonary Fibrosis. Danso Eizo kenkyukai Zasshi (Japanese Journal of Tomography) 2004; 31: 25-9.

Ryu JH, Colby TV, Hartman TE, Vassallo R. Smoking-related interstitial lung diseases: a concise review. Eur Respir J 2001 17: 122-32. 
Usui K, Tanai C, Tanaka Y, et al. The prevalence of pulmonary fibrosis combined with emphysema in patients with lung cancer. Respirology 2011; 16: 326-331.

Wiggins J, Strickland B, Turner-Warwick M. Combined cryptogenic fibrosing alveolitis and emphysema: the value of high resolution computed tomography in assessment. Respir Med 1990; 84: 365-369. 


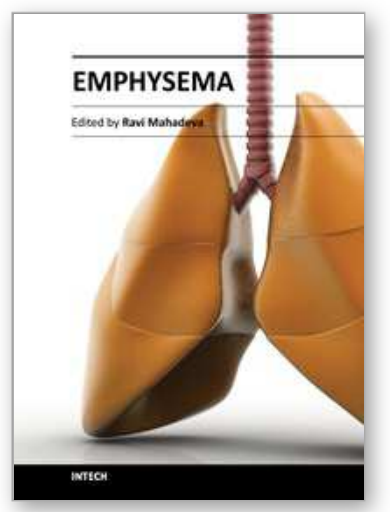

\author{
Emphysema \\ Edited by Dr. Ravi Mahadeva
}

ISBN 978-953-51-0433-9

Hard cover, 134 pages

Publisher InTech

Published online 30, March, 2012

Published in print edition March, 2012

Chronic Obstructive pulmonary disease (COPD) is an important cause of morbidity and mortality world-wide. The most common cause is chronic cigarette smoke inhalation which results in a chronic progressive debilitating lung disease with systemic involvement. COPD poses considerable challenges to health care resources, both in the chronic phase and as a result of acute exacerbations which can often require hospital admission. At the current time it is vital that scientific resources are channeled towards understanding the pathogenesis and natural history of the disease, to direct new treatment strategies for rigorous evaluation. This book encompasses some emerging concepts and new treatment modalities which hopefully will lead to better outcomes for this devastating disease.

\title{
How to reference
}

In order to correctly reference this scholarly work, feel free to copy and paste the following:

Keisaku Fujimoto and Yoshiaki Kitaguchi (2012). Combined Pulmonary Fibrosis and Emphysema (CPFE), Emphysema, Dr. Ravi Mahadeva (Ed.), ISBN: 978-953-51-0433-9, InTech, Available from: http://www.intechopen.com/books/emphysema/combined-pulmonary-fibrosis-and-emphysema

\section{INTECH}

open science | open minds

\section{InTech Europe}

University Campus STeP Ri Slavka Krautzeka 83/A 51000 Rijeka, Croatia Phone: +385 (51) 770447

Fax: +385 (51) 686166 www.intechopen.com

\section{InTech China}

Unit 405, Office Block, Hotel Equatorial Shanghai No.65, Yan An Road (West), Shanghai, 200040, China 中国上海市延安西路65号上海国际贵都大饭店办公楼405单元 Phone: +86-21-62489820

Fax: +86-21-62489821 
(C) 2012 The Author(s). Licensee IntechOpen. This is an open access article distributed under the terms of the Creative Commons Attribution 3.0 License, which permits unrestricted use, distribution, and reproduction in any medium, provided the original work is properly cited. 